\title{
Community involvement in the assessment of the importance of sustainable rural tourism indicators for protected areas: the case of the Nevado de Toluca National Park in Mexico
}

\author{
G. González Guerrero, M. E. Valdez Pérez \& R. Morales Ibarra \\ Centro Universitario UAEM Tenancingo, \\ Universidad Autónoma del Estado de México, México
}

\begin{abstract}
This paper uses objective sustainable tourism indicators in a subjective way to examine the importance that local people attaches to them. The legal rights that local people have over resources in Protected Areas make it not only important but also crucial that communities be involved in monitoring. For this reason it is necessary to know the importance they attach to indicators, which, in turn could be considered as a reflection of the importance they attach to resources. For the research, a revision of available indicators was conducted. Nineteen of these indicators were selected as being applicable to the context of the Nevado de Toluca National Park. Interviews were conducted with the local people in three parts. The first part referred to their perception of the tourism activity in the area, the importance they attached to each of the indicators using a 5-point Likert scale, and their knowledge ability on the subjects of sustainable development or tourism. The second part of the interview consisted of a set of 12 photos they had to order according to the importance they attached to them. These pictures were representative of the resources found in the Nevado Park and the community. The last part of the interview was meant to help characterise the household as regard to their livelihoods. The paper concludes that more work needs to be done with indicators at the community level. Because of the technicalities of indicators, there exists the risk of leaving the local people at bay even though sustainable tourism has called for community involvement. Although
\end{abstract}


interviewees attached importance to the monitoring of resources it is equally important that they understand their possible participation in it.

Keywords: rural tourism, sustainability indicators, community involvement, national parks, Mexico.

\section{Introduction}

Sustainable tourism emerged in response to growing concerns about the adverse impacts that tourism has resulted in the areas of environmental, social and even economic destinations. This was not the exception in rural areas, however, as mentioned by Wall [1] referring to the tourism that is practiced in areas that are predominantly natural "one might wonder if the average ecotourist puts more pressure on the environment the tourist who practice mass tourism and you may not need to see endangered species in remote locations and whose needs and waste can be more easily planned and managed.” However, despite latent adverse impacts, the growth of tourism does not stop. For this reason ways have been sought to lessen the impacts of tourism. Indicators have been seen as a way to monitor the effects of tourism on resources and local communities (World Tourism Organization [2]).

It has been concluded by Mowforth and Munt [3] that "sustainable tourism is only definable in terms context, control and position of those who define it." Based on this premise the same can be concluded about sustainability indicators. Thus the questions arise, who are developing sustainable tourism indicators? What is their context and position? Which stakeholders are involved in the monitoring and use of indicators? While one can argue for the development of indicators by 'experts' in the subject (Miller [4]) the movement toward decentralization, and tourism projects and natural resource management by local communities suggest the need for these communities to be actively involved in decision-making (Simmons [5], Scheyvens [6], Nunan [7]). Accordingly, there is a need to bring communities to the fore in the context of indicators for sustainable tourism (Blackstock et al. [8]).

\section{Sustainable rural tourism indicators}

After three decades sustainable tourism remains at the centre of debates that question its value and utility (Wall [1], Velikova [9], Liu [10]). What is the rationale for developing indicators for a concept that has been described as contradictory, ambiguous and unhelpful? In Miller's words [4], "the indicator development process can help determine the fundamental principles on which to base the concept". In other words, it is possible that through the development of indicators for sustainable tourism the concept itself may be built.

As mentioned (Lawrence [11]), "sustainability indicators can be an important tool to help individuals, institutions, communities and societies to build different and better options for their future.” The World Tourism Organization (WTO) designed and compiled in 1996 and then in 2004 a series of indicators for sustainable tourism. The focus of these indicators is on the welfare of host 
communities, the maintenance of cultural assets, the intensity of use, social impact, waste management, the planning process, critical ecosystems, consumer satisfaction, local content and the load capacity, among others. These documents have been prepared as a guide for those involved in planning and tourism management.

Some countries have developed frameworks according to their context. One example of it was the case of Korea, where the WTO's sustainable indicators were used to monitor the management activities of the Mt. Sorak National Park. The purpose of the study was to evaluate whether the park was being manage in a sustainable way. The findings were expected to assist in a change of the way in which the park was being managed (Kang [12]).

The Association of Caribbean States adapted a set of indicators considering some criteria such as security, identity and culture, child prostitution, employment in tourism, quality of bodies of water, energy consumption index, water consumption index, environmental management and use, efficiency of the solid waste management system, efficiency of the waste water management system, tourist satisfaction, and national and local product consumption index. The purpose was, again, to ensure the achievement of sustainability in the tourism activity (Association of Caribbean States [13]).

Miller [4] used a set of indicators to find out the consumer's point of view on the subject. The purpose was to find out whether or not tourists made decisions about their holidays based on the available information on sustainable practices in the destinations.

More comprehensive studies on indicators have been made in the last decade. For example, Lozano-Oyola et al. [14] develop an indicator system for cultural destinations. They propose goal programming to construct composite indicators and provide guidelines to use these tools for planning. However these attempts are aimed at tourism managers and local agents as main users, although they do suggest "a participative approach... to take advantage of local knowledge" (see also Blancas et al. [15]; Blancas et al. [16]). Choi and Sirakaya [17] use a Delphi technique to arrive at a set of 125 indicators that include the political, social, ecological, economical, technological and cultural dimensions. They state that this set will be used as a starting point to be later adapted to the characteristics of different communities. They also state that in further research they will seek the input of different stakeholder groups including local residents. Tsaur et al. [18] although employing the Delphi technique, they apply an integrated perspective by seeking the input of local residents, tourists and resource administrators to evaluate sustainability in an ecotourism destination in Taiwan. This study helps to illustrate that different stakeholders have different priorities. For example experts and resource administrators pointed at the environment as the most important factor in sustainability. Tourists were more concerned with highquality travel experiences. For the local people their livelihoods were the main factor. Thus, directly or indirectly, these studies show that there is a need for research that puts the local people at the centre of the discussion on sustainability and indicators. 


\section{Participation of the local people}

The need for local people to be involved in the development and use of indicators has been highlighted by authors such as Miller. He mentions, "if indicators of sustainable development and, further, the concepts of sustainable development and sustainable tourism must be accepted and understood by the general public, then they must be relevant to the public" (Miller [4]).

In similar terms, the Brundtland Report states: "the law alone cannot enforce the common interest. It principally needs community knowledge and support, which entails greater public participation in the decisions that affect the environment” (World Commission on Environment and Development [19]). Thus, the importance of involving local communities can be seen from two perspectives. On the one hand involving the local communities may help to avoid possible tension and conflict from viewing outsiders as the sole possessors of knowledge (Chambers [20]). On the other hand there is the fundamental right that communities have to engage in tourism from the point of view that ultimately they will receive not only the benefits but also costs of tourism (Johnson and Snepenger [21], Sharpley and Sharpley [22]).

The case of protected areas is different to other places of tourism activity in that decrees place restrictions on the use of resources which would imply a closer monitoring. The reality, however, is that in developing countries such as Mexico, budgets and personnel for monitoring are insufficient (Anderson and James [23], Gauld [24]). Local communities can thus be seen as suitable to monitor informally as they can closely perceive changes in the state of resources. In the Mexican context locals communities are not only suitable but also the most appropriate because many of these local communities have claims over the resources. As mentioned by Tsaur et al. [18] "residents could act as stewards of natural resources to effectively care for and conserve local resources”. However, in order to achieve the active involvement of local communities in monitoring and using indicators, these have to be meaningful for the local people (see also Yates et al. [25]).

\section{Study site: the Nevado de Toluca National Park}

The setting for this research is the Nevado de Toluca National Park. The park covers 53,988 hectares, of which official documents suggest that approximately 20,000 of these remain forested (CEPANAF et al. [26]). It has four sites that are officially regarded as tourist areas: el Mapa, Dos Caminos, the volcanic Crater and the Deer Park (see Figure 1). El Mapa and Dos Caminos and the Deer Park are part of the Zinacantepec Municipality. In these three tourist areas visitors have picnics, take walks or ride horses. However, only Dos Caminos and the Deer Park have tourism services and infrastructure, with the Deer Park considered being in slightly better condition (CEPANAF et al. [26]). El Mapa and Dos Caminos are closer to Toluca and Mexico City but farther from the main attraction of the Nevado Park: the Crater. 


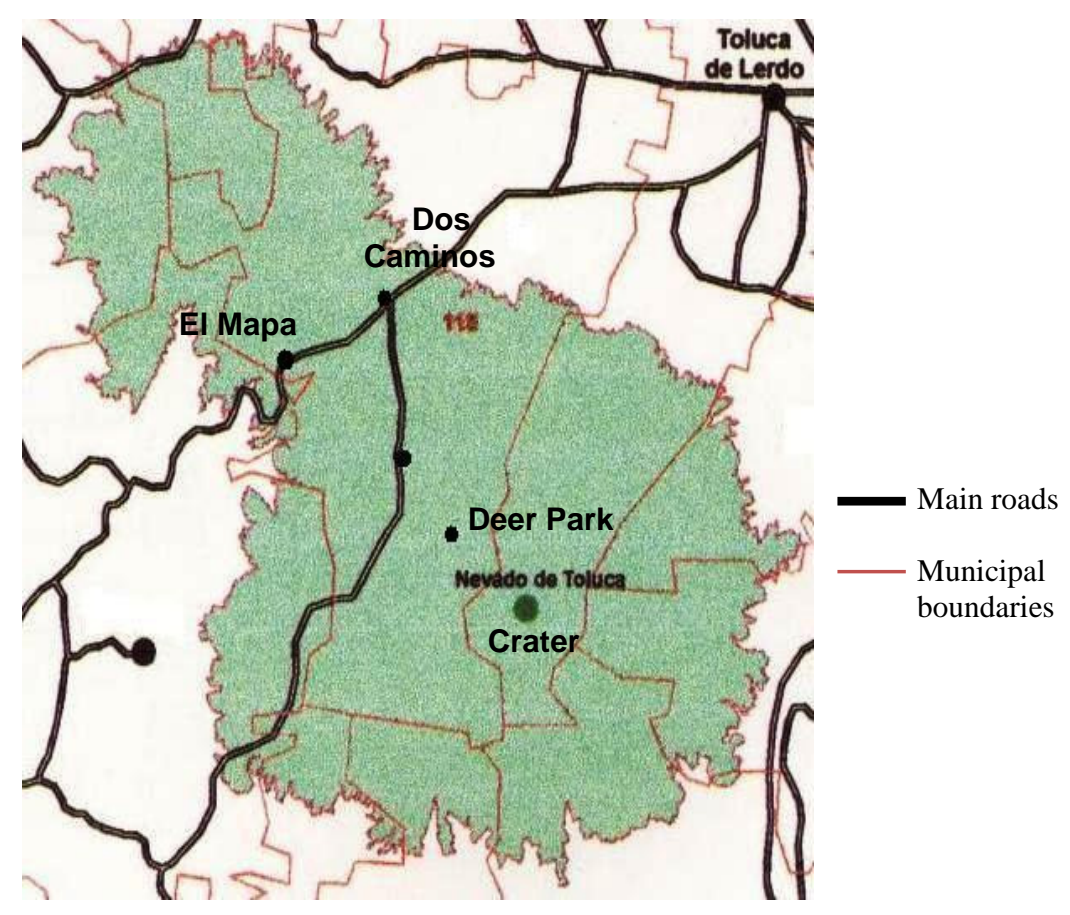

Figure 1: $\quad$ The Nevado de Toluca National Park and its main tourist areas.

As a National Park, the Federal Government of Mexico has a legal reason to be involved in its management, although some of the latest legal developments have meant that the federal government has delegated some of its responsibilities to the state government. This has given the state government a valid reason (and obligation) to be more actively involved than before. The municipal government's involvement is somewhat less clear, although the state government stakeholders appear to have expectations of its involvement. At the local level there are individual landowners and ejido members with clear group and individual land rights as well as other community members with interests in the park's resources, possibly simply for leisure activities.

The Nevado de Toluca National Park is home to 15 rural communities. The size of the settlements ranges from 2 to 500 houses. The size determines the number and kind of services that can be found in each. Potato and oats are the most common crops grown, although maize can be found in the lowest-lying areas. It is also common to come across herds of cattle or flocks of sheep being herded to grazing areas.

Most of the settlements were formally established in the first part of the $20^{\text {th }}$ century. Before then, what today is known as the Nevado de Toluca National Park was referred to by its nahuatl name Chignahuiltecatl (Nine Hills) or Xinantecatl Volcano. Most of its 53988 hectares were then divided amongst 
three haciendas: la Gavia, la Huerta and Tejalpa, which were formed after the conquest of Mexico in 1519.

The Nevado Park was constituted by decree in 1936. The decree made it clear that due to the ecological importance of the area, conservation was a priority and this could not be achieved if excessive exploitation (by ejidos or individual owners) prevailed. Owners affected by the decree were given a period of six months to prove their ownership, after which they would receive compensation for their land.

The decree was not fully executed in the Nevado Park; the area was declared a National Park but the individual land owners and ejido members were not compensated and did not leave the area. By the time of the decree most ejidos had already been formed. The Loma Alta ejido (a Zinacantepec ejido inside the Nevado Park), for example, was granted more land in August 1936, seven months after the decree. The decree meant that in the absence of compensation, ejidatarios and individual owners maintained their claims, but as they were inside the National Park heavy restrictions were imposed on the use of resources: The area already being used for agricultural purposes could continue as such, but the rest had to be left as a conservation area. In consequence the Nevado de Toluca National Park was made subject to three kinds of property rules: ejido, individual and federal property.

San Juan de las Huertas ( $\mathrm{SJH}$ ) is one of the communities with claims over the Nevado Park in the form of ejido with 2170 hectares. Its ejido manages the Deer Park, which is one of the main tourist sites of the Nevado Park. However, while the tourist area (Deer Park) is within the boundaries of the Nevado Park, the community itself is outside it. In practice this means that many ejidatarios and community members may not necessarily be aware of what happens in the tourist area.

From the perspective of the rural/urban dichotomy SJH can be categorised as an urban community. In 1973 its population had already surpassed the size considered rural because of its population size. By 2005 the community already comprised 11,835 inhabitants divided amongst 2562 households, according to the official census (Instituto Nacional de Estadística Geografía e Informática [27]). However, it cannot be said that SJH automatically became urban the year it exceeded 2500 inhabitants. The process of change has been long and a diversity of factors beyond population size has contributed to it. It is in this setting and in this community that the research was conducted.

\subsection{Methodology}

For this research the indicators provided by the WTO were reviewed. Of all the indicators proposed by the organization, those that could be applicable to the setting of the Nevado Park were chosen. Nineteen were shortlisted as being the most relevant. Although quantitative in nature, the indicators were used in a qualitative way in order to gain insight into what local people thought was relevant to monitor regarding the available resources and the tourism activity.

Interviews were designed in three parts. The first part referred to their perception of the tourism activity in the area. Interviewees were asked to attach 
importance to each of the indicators using a 5-point Likert scale. Five points were used for very important and 1 for non-important. This first part of the interview was also used to explore their knowledge ability on the subjects of sustainable development and/or sustainable tourism.

The second part of the interview consisted of a set of 31 photos the interviewees had to arrange in order or importance. These pictures were representative of the resources found in the Nevado Park and the community. But also included pictures meant to represent education, income and family.

The last part of the interview was meant to help characterise the household as regard to their livelihoods. This characterisation included age, maximum education level, occupation, marital status of each household member. It also included the resources that they may own as household (i.e. livestock, land, business, etc.).

The interview was tested with 5 ejidatarios randomly chosen as they arrived to the office of the Ejidal Comisariado (the representative of the ejidatarios). The results from the test showed that for the first part of the interview some indicators had to be re-worded to make them more understandable. The second part of the interview showed that 31 photos were too many. Some of them, the ejidatarios said, were repetitive of resources and were therefore placed consistently on the same level. Therefore, the photos were reviewed to reduce the number to 12 . This was done while trying to make sure that the photos of the resources that intended to be represented remained. It was also noticed that some photos were attached different meanings by ejidatarios. For this reason it was thought necessary to specify what the picture meant to represent for the research. This was not to be made known to ejidatarios. However, after they finished arranging the pictures in order of importance they would be asked to explain what each picture represented to them. No changes were made to the third part of the interview because it was meant to help characterise the households and their livelihoods. It was expected that some ejidatarios would perceive the questions as too personal to answer, so they were explained that they did not have to answer if they did not feel comfortable with a particular question.

After these modifications were made to the interview script, a list of ejidatarios was obtained from the Ejidal Comisariado's office. Using a random numbers table, 40 ejidatarios were selected. It was planned to conduct only 22 interviews but an extra 18 names were obtained in case some ejidatarios refused to participate or could not be found.

In addition to these interviews informal conversations were held with various members of the community. Meetings of the ejido were also attended as observant. This allowed examining the dynamics of these meetings and the interaction of ejido members.

It should also be mentioned that although this particular project had duration of one year, research in this area has been conducted for the past 7 years. Therefore, some of the information obtained from this project is analysed in light of information already available. 


\section{Community involvement in the Nevado de Toluca National Park}

\subsection{The relation of the local people with the resources}

The population of SJH once depended on farming activities but has now diversified or completely shifted to activities within manufacture or services. However, in absolute terms 400 or more households still depend on arable farming and livestock production. Furthermore, not only ejidatarios work in this field but also non-ejidatarios cultivate other people's land, renting it from ejidatarios that do not use it or hiring themselves to work on ejidatarios' land. A small number of ejidatarios also farm livestock. Cattle and sheep are the most common. The livestock are sometimes kept for weeks or months in provisional corrals in the upper area of the Nevado Park, where there is most pasture. People living in the communities in that area are sometimes hired to look after them.

It is also important to consider the people's relations to resources. The population of $\mathrm{SJH}$ uses forest resources in various ways. As it is an urban settlement, most households use gas instead of wood as fuel. Yet official figures register that in 2000, 3.28 percent of households still used wood to cook (Instituto Nacional de Estadística Geografía e Informática [28]). Apart from personal consumption, residents of SJH complained of wide illegal exploitation of the forest for profit because the Nevado Park is not appropriately guarded. Nobody appears to know who is responsible for this. Some believe that members of other communities are involved, while others say that the offenders are not from any of the nearby communities but are rich people that can afford to violate the law without major consequences. Other forest resources are also exploited, with the collection of wild fruits, medicinal herbs, fibres and other forest products for consumption and sale. It is also argued that community members, particularly farmers, extract soil illegally to sell to private nurseries (CEPANAF et al. [26]).

There are non-ejidatarios who have a relationship with the natural resources of the ejido based on claims of ownership and pride of possession (González Guerrero [29-31]). Being that the ejido is linked directly with the community some non-ejidatarios believe they have claims of ownership that need to be recognized. This complex relationship that the local people have with the resources shows the relevance of including them in monitoring processes and in the planning and use of indicators.

\subsection{The importance of indicators}

The indicators were emptied on a table and average numbers were obtained from the results given by interviewees. One of the first things that can be highlighted from the results is that 7 interviewees considered that all 19 indicators were "very important" as they gave an equal mark of 5 to all of them. This shows that, at least for these 7 people, the monitoring processes of the impacts of tourism on the resources and community are extremely important. 
It can also be observed that according to the responses, the most important indicator was "increase or decrease of wildlife diversity" with an average of 4.64. Conversely, the least important indicator as per the responses was "adverse social effects" with an average of 3.77. This result seems to be in contrast with a research concluded 2 years ago in the same area. During this research, negative social changes in the community were raised as a main concern of many of the interviewees (see González Guerrero [29]). Back then interviewees argued that young people was acquiring the habit of drinking on street corners in the afternoons, making the community increasingly unsafe. However, this apparent contradiction can be explained by two main points. Firstly, the context given by most of the other indicators may have given the interviewee a sense that indicators regarding conservation and protection of resources were more important. Secondly, as both the tourism activity and the natural resources are outside the immediate geographical area of the community, it may have been difficult to relate them to "adverse social effects" in the community.

Another indicator that had a low average was "national/international organizations involved in development/conservation strategies”, with 4.09 points. This is consistent with a generalised view in the ejido that people from outside the community should not become involved in matters of the community or the ejido. This view could also be observed at the ejido meetings. Apart from the conflicts that there were between different ejidatarios, a feeling of mistrust of government institutions was expressed by several participants at the meeting.

However, the interviewees do believe that "the community should be involved in planning and decision making concerning the tourism activity”. This indicator ranked 4 in order of importance with 4.41 points. This shows that they want to be involved. It is also a reflection of their view that even though they may accept the involvement of national or international organisations, the community's decision should be above the input of stakeholders external to it.

It is also noteworthy that the indicator "visitors aware of the conservation and preservation of natural resources" ranked 3 in order of importance. Comparatively, the indicator "local people aware of the conservation and preservation of natural resources" ranked 8 in order of importance. This means that while the interviewees consider that the community should be aware of conservation and preservation of resources a greater responsibility is placed on the visitors for this same purpose. This could again be attributed to the fact that the tourist area (the Deer Park) is not in close proximity to the community. From this point of view it can be easier for visitors to be aware of circumstances in the Deer Park than for ejidatarios who are not appointed to watch over it. Additionally, these figures can be interpreted as ejidatarios expecting visitors to act responsibly while visiting the Deer Park.

\subsection{The discourse of sustainable development}

From the 22 interviewees, 16 had not heard of sustainable development or sustainable tourism and they did not know the meaning of either term. Four mentioned to have heard of it but did not know what it meant. Two had heard about sustainable development. When asked to explain its meaning, both related 
it to governmental programmes. They said that sustainable development was about subsidies that the government gave to plant trees and prevent fires in the Nevado Park. This view is result of a prevalent discourse on sustainable development in governmental institutions. This discourse is not only reflected in policy documents but it is also part of the official speech of government representatives (see González Guerrero [29]).

\section{Conclusions}

This study has only been a first approximation to resident attitude towards indicators. It has shown that even though most interviewees did not know the meaning of sustainable development or had even heard about it, they did attach importance to indicators. This shows that monitoring impacts of the tourism activity on resources is important to the local people even though they do not have a name for it. It is thus necessary that sustainable development, indicators, principles, etc. stop being the domain of experts, academics, politicians and international organizations and permeate to the local people.

More research is needed that brings local people to the fore of sustainable development. This requires looking for more creative ways and methodologies that enable bringing the discussion on sustainability and indicators to the local level. This in turn would enable local input into the development and use indicators. Following the movement towards decentralisation this is not only desirable but also a necessity. This is also reflected in the views of the interviewees when they attach more importance to the indicator that shows input from the local people than to the indicator that measures the involvement of national and international stakeholders.

\section{References}

[1] Wall, G., Sustainable tourism - unsustainable development (Chapter 3). Tourism, development and growth. The challenge of sustainability, eds. S. Wahab and J.J. Pigram, Routledge: London, pp. 33-49, 1997.

[2] World Tourism Organization, What tourism managers need to know. A practical guide to the development and use of indicators of sustainable tourism, World tourism Organization: Spain, 1996.

[3] Mowforth, M. and Munt, I., Tourism and sustainability. New tourism in the third world, Routledge: London and New York, 2003.

[4] Miller, G., The development of indicators for sustainable tourism: results of a Delphi survey of tourism researchers. Tourism Management, 22(4), pp. 351-362, 2001.

[5] Simmons, D., Community participation in tourism planning. Tourism Management, 15(2), pp. 98-108, 1994.

[6] Scheyvens, R., Ecotourism and the empowerment of local communities. Tourism Management, 20(2), pp. 245-249, 1999.

[7] Nunan, F., Empowerment and institutions: Managing fisheries in Uganda. World Development, 34(7), pp. 1316-1332, 2006. 
[8] Blackstock, K.L., et al., Measuring responsibility: An appraisal of a Scottish National Park's sustainable tourism indicators. Journal of Sustainable Tourism, 16(3), pp. 276-297, 2008.

[9] Velikova, M.P., How Sustainable is Sustainable Tourism?. Annals of Tourism Research, 28(2), pp. 496-499, 2001.

[10] Liu, Z., Sustainable Tourism Development: A Critique. Journal of Sustainable Tourism, 11(6), pp. 459-475, 2003.

[11] Lawrence, G., Getting the future that you want: the role of sustainability indicators. Community and sustainable development: Participation in the Future, ed. D. Warburton, Earthscan: London, pp. 68-80, 1998.

[12] Kang, M.H., Monitoring the management of Mt. Sorak National Park utilizing WTO's sustainable tourism indicators. Journal- Korean Forestry Society, 12, 2002.

[13] Association of Caribbean States. Convention establishing the sustainable tourism zone of the Caribbean. Online. http://www.acs-aec.org/ Tourism/VII/english/Legalturdoc_eng.htm

[14] Lozano-Oyola, M., et al., Sustainable tourism indicators as planning tools in cultural destinations. Ecological Indicators, 18(0), pp. 659-675, 2012.

[15] Blancas, F.J., et al., Goal programming synthetic indicators: An application for sustainable tourism in Andalusian coastal counties. Ecological Economics, 69(11), pp. 2158-2172, 2010.

[16] Blancas, F.J., et al., How to use sustainability indicators for tourism planning: The case of rural tourism in Andalusia (Spain). Science of The Total Environment, 412-413(0), pp. 28-45, 2011.

[17] Choi, H.C. and Sirakaya, E., Sustainability indicators for managing community tourism. Tourism Management, 27(6), pp. 1274-1289, 2006.

[18] Tsaur, S.-H., Lin, Y.-C., and Lin, J.-H., Evaluating ecotourism sustainability from the integrated perspective of resource, community and tourism. Tourism Management, 27(4), pp. 640-653, 2006.

[19] World Commission on Environment and Development, Our common future, Oxford University Press: Oxford, 1987.

[20] Chambers, R., Rural development: putting the last first, Pearson Education Limited: Essex, 1983.

[21] Johnson, J.D. and Snepenger, D.J., Residents' perceptions of tourism development. Annals of Tourism Research, 21(3), pp. 629-642, 1994.

[22] Sharpley, R. and Sharpley, J., Rural Tourism: An Introduction. International Thompson Business Press: London, 1997.

[23] Anderson, T.L. and James, A., Introduction: Parks, politics and property rights. Parks in peril. People, politics and protected areas, eds. K. Brandon, K.H. Redford, and S.E. Sanderson, Island Press: Washington, 1998.

[24] Gauld, R., Maintaining centralized control in community-based forestry: Policy construction in the Philippines. Forests. Nature, people, power, eds. M. Doornbos, A. Saith, and B. White, Blackwell: Oxford and Malden, p. 223-248, 2000. 
[25] Yates, G.E., Stein, T.V., and Wyman, M.S., Factors for collaboration in Florida's tourism resources: Shifting gears from participatory planning to community-based management. Landscape and Urban Planning, 97(4), pp. 213-220, 2010.

[26] CEPANAF, Biocenosis, and UAEM, Programa de Manejo del Parque Nacional Nevado de Toluca. CEPANAF, Biocenosis, and UAEM: Toluca, Undated.

[27] Instituto Nacional de Estadística Geografía e Informática, II Conteo de Población y Vivienda 2005. Principales resultados por localidad. INEGI: México, 2006.

[28] Instituto Nacional de Estadística Geografía e Informática, XII Censo General de Población y Vivienda 2000. Principales resultados por localidad. INEGI: México, 2000.

[29] González Guerrero, G., Community organisation for tourism: A Mexican case study. University of East Anglia: Norwich, 2009.

[30] González Guerrero, G., Questioning the meaning of participation and social equality in sustainable tourism based on the experience of a communitybased initiative in Mexico. Tourism Futures: Creative and Critical Action, ed. R. T., Ward, Welsh Centre for Tourism Research: Cardiff, 2011.

[31] González Guerrero, G., Local Participation in a Sustainable Ecotourism Initiative: A Collection of Narratives on the Deer Park. Journal of Tourism, X(X), pp. 51-71, 2012. 